\title{
Structural equation model with partial least square (SEM-PLS) of place dependence with land used change
}

\author{
Gunawan Prayitno \\ Universitas Brawijaya, \\ Malang, Indonesia \\ gunawan_p@ub.ac.id
}

ORCID 0000-00034534-9524

\author{
M Iqbal Ahari \\ Universitas Brawijaya, \\ Malang, Indonesia \\ mubiqbalashari@gmail.com
}

\author{
Wara Indira Rukmi \\ Universitas Brawijaya, \\ Malang, Indonesia \\ waraindiraub@yahoo.com
}

Abstract. The phenomenon of land conversion continues to increase due to the rise in population, thereby increasing the demand for housing and other facilities rapidly. The attachment of population to a place creates a special relationship with the surrounding environment. Place dependence is defined as a form of population attachment to a place in terms of functional dimensions, in such a way that it provides benefits for people to meet their needs. The existence of this attachment is expected to affect a person's decision regarding land conversion. This study aims to determine the relationship between population place dependence and land conversion (decision change or not). The data were empirically obtained from 500 households that owned land in the sub-district of Pandaan District, Pasuruan Regency, East Java, Indonesia, and analyzed using the structural equation model (SEM) partial least square analysis technique. The existence of this place dependence is expected to affect a person's land conversion decision.

Keywords: land conversion, attachment, place dependence, structural equation model (SEM), Indonesia.

JEL Classification: A13, C89, Q15, R14 


\section{INTRODUCTION}

The relationship between a place and human emotions has been widely examined in environmental and human geography studies. The place-based theory states there is an emotional relationship between humans and places (Anton \& Lawrence, 2016; Lin \& Lockwood, 2014; Lokocz et al., 2011). Places known or occupied by someone have a special value formed through personal interaction with the place, creating attachments (Burley, 2010).

A measure of attachment can be carried out using place attachments. This is a dimension of sensitivity to a place and a positive emotional attachment between a place and an individual. Its formation results from personal interaction with the place. Residents gain a perspective through biography, micro- and macrocultural meanings, sociohistorical moment, and time (Burley, 2010). Place attachment is an attachment between humans and the place they inhabit (Prayitno et al., 2019). It provides a reciprocal relationship between humans and the environment in terms of residence, workplace, or everyday environment.

The measurement in place attachments from various scientific fields is the difference between emotional and functional dimensions (Lin \& Lockwood, 2014). The emotional dimension (symbolic bond) is interpreted as the place identity while the functional dimension is the place dependence. The emotional dimension is shown through the feelings arising when in a place. In contrast, the functional dimension is shown in person's action or the feeling of benefit from a place (Anton \& Lawrence, 2016). Trabka (2019) defined place attachment as a process explained through four dimensions - place identity, place dependence, place discovered, and place inherited.

Place dependence is a functional dimension or bond (Anton \& Lawrence, 2016). It is also the resident's perception of the value and the capacity of a place to meet their needs as compared to other places (Fenando in (Butu et al., 2018). It shows that the place inhabited fulfils the population's functional needs and goals (Suntikul \& Jachna, 2016). Place dependence is a functional bond formed when its capacity meets the needs of residents of a place. The population aims to live and work comfortably (Trabka, 2019). The fulfilment of this goal depends on the capacity of the place of residence. For instance, Oslo and London provide promising careers and income, hobby activities, stress-free work, and the closeness of the residential environment with nature. Each aspect contributes to the life of local population. Promising income provides certainty to fulfil needs, while career opportunities provide job comfort and income, a hobby facilitated by easy and affordable access to the places needed, and closeness to nature provides a healthier lifestyle. The benefits obtained from an area are generated through a certain time limit, and the closeness to the area of origin (Trąbka, 2019).

Since the reasons for attachment can be different, this study determines how residents in developing countries relate to places. The case studied is Pandaan Subdistrict, Pasuruan Regency, Indonesia. Pandaan is a sub-district, rapidly developing because it is related to the development of the Malang Surabaya toll road. Also, it is an expansion of settlements from Surabaya City.

Based on the Regional Spatial Plan of Pasuruan Regency 2009-2029 and the Indonesian Government Regulation number 26 as of 2008, Pandaan Subdistrict is part of the Pasuruan Regency, functioning as a Local Promotion Activity Center (PKLp -Pusat Kegiatan Lokal promosi). Additionally, it is an activity centre serving one district, and therefore, it requires facilities and infrastructure to fulfil its functions. One critical infrastructure object in the district is the main road connecting Surabaya City with Malang City and GempolPandaan toll road. The roads provide residents with convenience in activities and help them satisfy their daily needs (Trabka, 2019). The residents do not experience financial problems since their daily expenditure does not exceed their income (Prayitno et al., 2018).

Pandaan sub-district could be affected by the land-use change because it is a strategic area, traversed by several major road networks, leading to its development (Rusmi, 2019). In 2019, there was a change in 
the land use of 441.05 ha (Prayitno et al., 2020). These changes adjust to the community's social, economic, political, and cultural conditions (Verburg et al., 2015). Social conditions can be demonstrated by place attachment in the context of the theory of environmental psychology (Raymond et al., 2010, 2017). This can also be explained by place dependence, one of its dimensions.

Our research specifically discusses place dependence as being limited. This is because most works focus on place attachment as a whole. Most studies assert that place dependence might occur when residents feel their needs are fulfilled following their goals. (Aulia Rusmi, 2019; Haryani et al., 2019; Trąbka, 2019) stated that residents want to live and work comfortably, therefore, place dependence is much influenced by physical aspects of residence, providing a sense of comfort. Furthermore, (Clarke et al., 2018) established that certain regional environmental features contribute to the attitude of population adaptation during natural disasters. The research related to place attachment with the wider environment, such as agricultural land, has not been extensively conducted yet, to the best of our knowledge. This research explores empirical data on how place dependence is related to the wider environment, such as agricultural land and a place of work. It determines, using the SEM method, whether there is a relationship between place dependence and the attitude of changing land .

\section{LITERATURE REVIEW}

\subsection{Place attachment}

A person's satisfaction and love for a residential environment (place attachment) is an essential Environmental Psychology concept. Place attachment is science relevant to environmental perception. It refers to the formation of one's inner bonding to a place, such as a residential environment (Ernawati, 2014; Lin \& Lockwood, 2014). This inner bonding positively provides community welfare and happiness in people's lives. Conversely, its absence gives a sense of alienation and uncomfortable in the environment, creating a negative psychological impact on the residents.

It is important to learn place attachment to maintain the attractiveness and meaning of a place. This helps preserve the value of a place for someone with an impact on the sustainability of feeling. Measuring place attachments can be carried out using 3 (three) variables and 5 (five) dimensions, providing valid results (Raymond et al., 2010).

Measurement of place attachments based on personal variables focuses on place identity and dependence (Lin \& Lockwood, 2014). Place dependence measures emotional attachment to a place. Similarly, place identity determines attachment since it is vital in an individual's life (Christy \& Sahrani, 2016). Therefore, the personal context was identified in place identity and place dependence.

Place identity has become essential in urban planning and design. It is an essential concept in geography, urban planning and design, and landscape architecture. Place identity concept reviews the relationships in "who we are," "where we are" and "how our local environment, including geographical location, cultural traditions, and cultural heritage, affects our lives" (Ernawati, 2014). It emphasizes the meaning and significance of a place to its residents and users.

Place dependence is visible in the functional bonds between individuals and a place regarded as a dependency. There are two components of place dependence, including the place quality, the availability of physical and social resources for individual goals, and how it is compared to other areas (Jatmiko, 2016). Place Dependence occurs when physical and social resources in the environment meet the individual needs of residents (Smith, 2011). 


\subsection{Place dependence}

Place dependence refers to the resident's perception of a place value and capacity compared to other places in fulfilling their needs (Butu et al., 2018). It is a sign that the place inhabited fulfils the population's functional needs and goals (Suntikul \& Jachna, 2016). For example, a rafter may only achieve chosen goals and activities on a river with rapids or strong currents (Udah, 2019). Residents in an area want to achieve a level of economic viability. The regional economic viability increases people's awareness of the place they live in, even though they do not always monitor their connection to the place or compare the quality of life with individuals in other communities. Therefore, a person can be resilient and reluctant to leave a place that offers a means of livelihood. People develop place dependence and remain in an environment that fulfils their needs, even when they are dangerous (Butu et al., 2018). The purpose of the population in a place is the primary determinant of functional attachment. Living and working comfortably drives a person to settle in a place (William cited in (Trąbka, 2019)).

\subsection{Land use change}

Land use is any permanent or cyclic human intervention on a group of natural and artificial resources to meet material and spiritual needs (Hasyim, 2020; Malingreau, 1977). Land requirements increase with time. An increase in population results in a high number of residents to be accommodated in a land. Furthermore, regional socio-economic development triggers the conversion of land functions (Siciliano, 2012).

In Pandaan Subdistrict, residents wanted or planned to sell their land because of high prices (Prayitno, Sari, et al., 2019). Sandy, cited in (Aulia Rusmi, 2019) stated that the decision to change land could have an economic and environmental impact and benefits. According to (Prayitno, Dinanti, et al., 2019), the benefits of selling land included fulfilling their needs in business, medical expenses, renovating a house, building a holy place, pitra yadnya/cremation ceremony, gambling, drinking, and spree. Changes in land use seem to be a complex phenomenon caused by various factors. However, economic benefits are the biggest motivation for residents to sell land.

\section{METHODOLOGY}

\subsection{Method of data collection}

Data collection methods were carried out in two stages, primary data collection through direct observation and secondary data collection from related agencies and literature studies. The data collected was arranged to suit the needs and maximum use. Processing techniques included descriptive statistics and SEM-PLS analysis. Sample size determination in social research used the calculation of Krejcie and Morgan (Ganji et al., 2020). The sample used was the family heads in Pandaan Sub-district, owning agricultural land. The number of family heads in the Pandaan Subdistrict in 2019 was 30,930, and therefore, the result of the sample calculation was 500 family heads owning land. The distribution of the number of samples in each village is based on the percentage of unused land area under ownership. The wider the unused land area, the greater the number of respondents.

\subsection{Partial least square}

The data analysis technique was Partial Least Square (PLS). This is part of the Structural Equation Model (SEM), which examines the relationship between variables reciprocally (Sholihin \& Ratmono, 2013). 
PLS is SEM with indicators consisting of formative and reflective variables. Initially, PLS was introduced to overcome the limitations of ordinary least square regression. When the number of data samples is small, there are missing values, and data is abnormally distributed with multicollinearity (Kock, 2015).

The initial model specifications in PLS are based on the researchers' theories. The data collected is processed using SEM-PLS. The following is an initial model of the relationship between research variables related to place dependence and land-use change (Figure 1). On land-use change, the focus is on the people's decision to change the land owned. Decision making is mediated by the assessment of the population on the development of occurring situations.

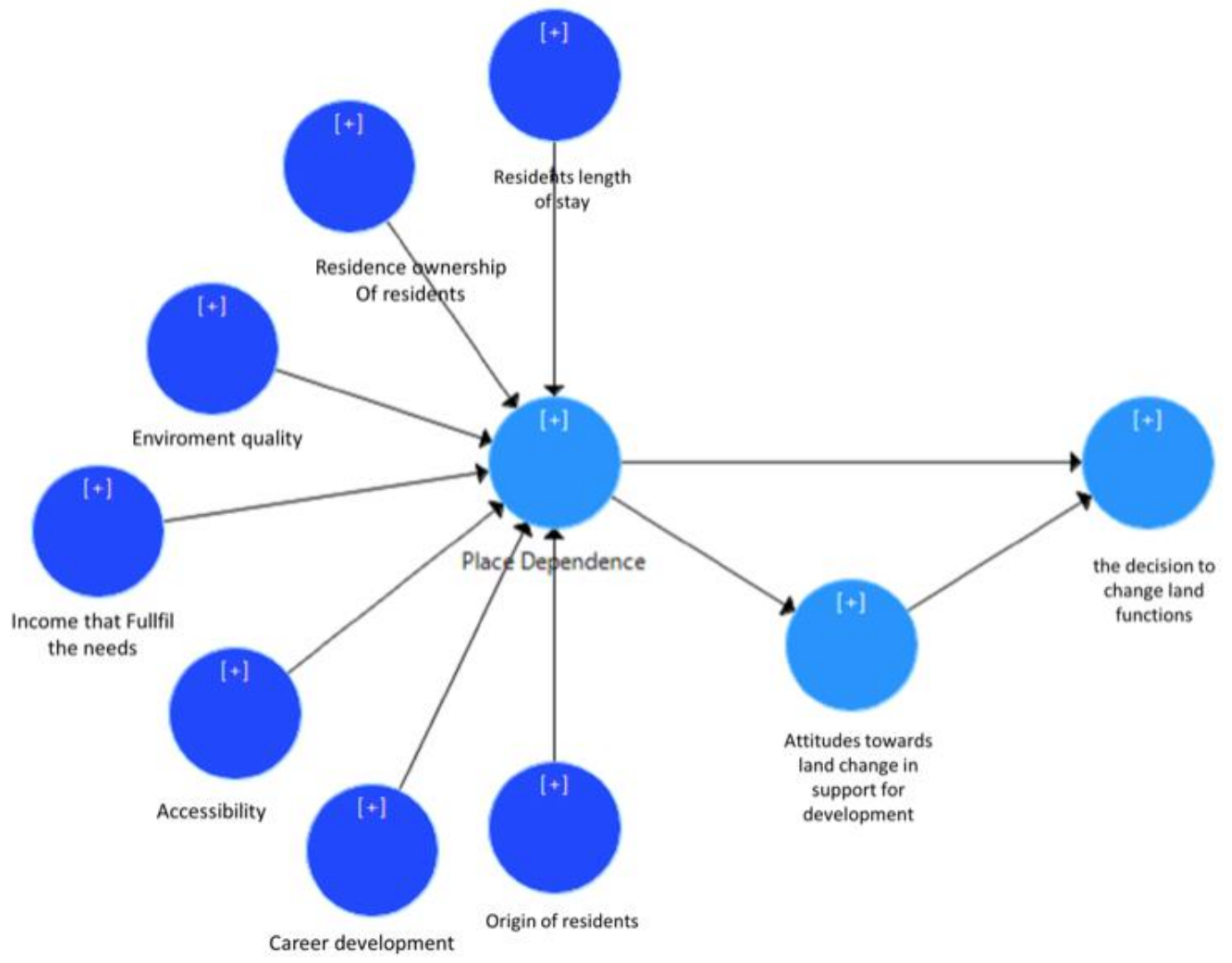

Figure 1. Structural equation model (research model)

Source: own compilation

(Lai \& Kreuter, 2012) define that the goals of the population are the activities desired to be fulfilled in their region. This means that the residents try to determine how to fulfil their needs in their area. (Clarke et al., 2018) stated that certain regional environmental features contributed to the attitude of population adaptation during natural disasters. Therefore, the research variables in place dependence can be summarized as follows: 
Table 1

Place Dependence Variables

\begin{tabular}{|l|l|}
\hline \multicolumn{1}{|c|}{ Variable } & \multicolumn{1}{c|}{ Source } \\
\hline - Origin of residents & (Baldwin et al., 2017; Haryani et al., 2019; Lai \& Kreuter, \\
- Residents' length of stay & 2012; Rao, 2018; Sina \& Raturomon, 2015; Trąbka, \\
- Residence ownership of residents & 2019) \\
- Environmental quality & \\
- Income that fulfills the needs & \\
- Accessibility & \\
- Career development & \\
\hline
\end{tabular}

Source: own compilation, 2020

Base on the literature review, the research indicator are as follows:

Table 2

Research indicators

\begin{tabular}{|c|c|c|c|}
\hline Variable & Sub Variable & Indicator & Sources \\
\hline \multirow[t]{3}{*}{$\begin{array}{l}\text { Land } \\
\text { Change }\end{array}$} & $\begin{array}{l}\text { The Area of } \\
\text { Land Use }\end{array}$ & $\begin{array}{l}\text { There has been a change in the area of land use between built } \\
\text { and un built land }\end{array}$ & $\begin{array}{l}\text { Winoto in (Prayitno et } \\
\text { al., 2020); Mahadi, } 2013\end{array}$ \\
\hline & $\begin{array}{l}\text { Attitude towards } \\
\text { development }\end{array}$ & 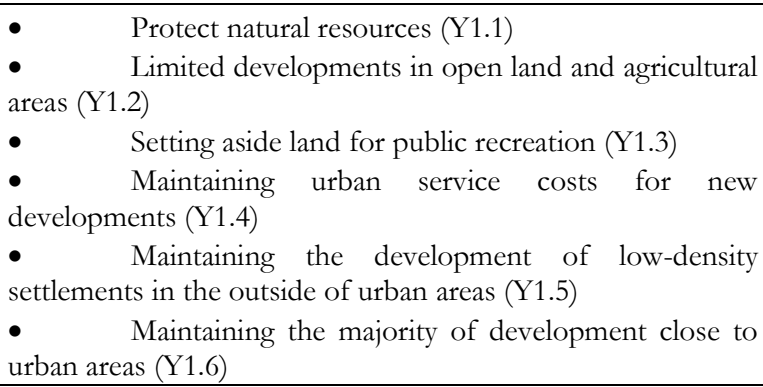 & (Lokocz et al., 2011) \\
\hline & $\begin{array}{l}\text { Decision to } \\
\text { Change the Land }\end{array}$ & I am willing or not willing to change the land & $\begin{array}{l}\text { Winoto in Rusmi, } \\
2019 ; \quad \text { Sandy in } \\
\text { Prayitno, 2019 }\end{array}$ \\
\hline \multirow[t]{4}{*}{$\begin{array}{l}\text { Place } \\
\text { dependence }\end{array}$} & $\begin{array}{l}\text { Origin of } \\
\text { population }\end{array}$ & Origin of resident area (X1) & Trabka, 2019 \\
\hline & Length of stay & $\begin{array}{l}\text { How many years the population lived in the Pandaan sub- } \\
\text { district (X2) }\end{array}$ & Trabka, 2019 \\
\hline & $\begin{array}{l}\text { Housing } \\
\text { ownership: } \\
\text { - } \quad \text { Consid } \\
\text { erations for } \\
\text { choosing a place } \\
\text { to live } \\
\text { - } \\
\text { on to meet needs }\end{array}$ & $\begin{array}{l}\text { - I choose to stay here because my food and drink } \\
\text { needs are met and I know where to meet my needs (X3.1) } \\
\text { - } \quad \text { I choose to stay here because my clothing needs are } \\
\text { met and know where to meet my needs. (X3.2) } \\
\text { - } \quad \text { I choose to stay here because my rest needs are met } \\
\text { and I know where to meet my needs. (X3.3) } \\
\text { - } \\
\text { met and I know where to meet my needs. (X3.4) } \\
\text { - } \\
\text { were met (X3.5) } \\
\text { - } \\
\text { met and I know where to meet my needs. (X3.6) } \\
\text { - } \\
\text { met and I know where to meet my needs. (X3.7) } \\
\text { - } \\
\text { are met and I know where to meet my needs. (X3.8) } \\
\text { - } \\
\text { my talents and abilities were met. (X3.9) }\end{array}$ & $\begin{array}{l}\text { Baldwin et al, 2017; } \\
\text { Moore \& Graefe in } \\
\text { Rusmi, 2019; William } \\
\text { \& Vaske in Rusmi, } \\
\text { 2019; Rao, 2018; } \\
\text { Minderop in Hikma, } \\
\text { 2015; Trabka, 2019 }\end{array}$ \\
\hline & $\begin{array}{l}\text { Environment } \\
\text { Quality: }\end{array}$ & $\begin{array}{l}\text { I have a good neighbor (X4.1) } \\
\text { Security in my environment is good (X4.2) }\end{array}$ & $\begin{array}{l}\text { Humon in Haryani, } \\
\text { 2019; Lai et al 2012; } \\
\text { Aragones }\end{array}$ \\
\hline
\end{tabular}




\begin{tabular}{|c|c|c|c|}
\hline Variable & Sub Variable & Indicator & Sources \\
\hline & $\begin{array}{l}\text { - Neigh } \\
\text { bors relations } \\
\text { - Safe } \\
\text { environment } \\
\text { - Settle } \\
\text { ment density } \\
\text { of State } \\
\text { of the } \\
\text { infrastructure } \\
\text { - Settle } \\
\text { ment facilities } \\
\text { - Health } \\
\text { facilities }\end{array}$ & $\begin{array}{l}\text { - The population of the house in my neighborhood is } \\
\text { not dense (X4.3) } \\
\text { - } \\
\text { The infrastructure in my environment is good (X4.4) } \\
\text { - } \\
\text { Housing facilities no problem (X4.5) }\end{array}$ & $\begin{array}{l}\text { Corraliza, } 1992 \text { in } \\
\text { Amerigo and Argones, } \\
\text { 1997, Trabka, } 2019\end{array}$ \\
\hline & Enough Income & 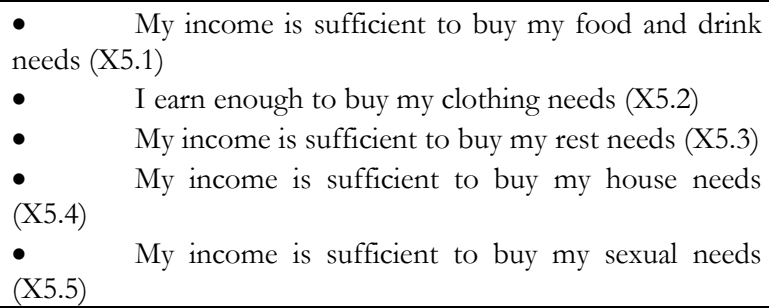 & $\begin{array}{l}\text { Moore \& Graefe in } \\
\text { Aulia, 2019; William \& } \\
\text { Vaske in Prayitno, } \\
\text { 2019; Trabka, 2019; } \\
\text { Minderop in Hikmah, } \\
2015\end{array}$ \\
\hline & $\begin{array}{l}\text { Accessibility: } \\
-\quad \text { Have } \\
\text { access } \\
\bullet \quad \text { Afford } \\
\text { able costs }\end{array}$ & 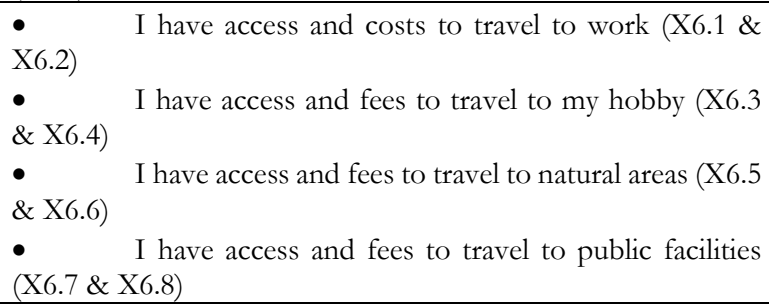 & $\begin{array}{l}\text { Willam in Haryani, } \\
\text { 2019; Trabka, } 2019\end{array}$ \\
\hline & $\begin{array}{l}\text { Career } \\
\text { development }\end{array}$ & $\begin{array}{l}\text { - } \text { I feel able to do my work with my physical abilities } \\
\text { (X7.1) } \\
\text { - I don't feel pressured due to mental activity to } \\
\text { concentrate, detect problems, and overcome unexpected } \\
\text { events during work (X7.2, X7.3, X7.4) } \\
\text { - } \quad \text { I am able to do my assignments accor-ding to my } \\
\text { target in a certain time (X7.5) }\end{array}$ & $\begin{array}{l}\text { Lai et al, 2012; Trabka, } \\
\text { 2019; Menpan in } \\
\text { Hadidya, } 2018\end{array}$ \\
\hline
\end{tabular}

Source: own compilation, 2020

\section{EMPIRICAL RESULTS AND DISCUSSION}

\subsection{An overview of the Pandaan Sub-district area}

Pandaan Sub-district has an area of 43.29 ha, with 14 villages and 4 urban villages. The selection of the Pandaan Sub-district as the study location was attributed to its strategic location, between the connecting lines of Malang and Surabaya cities. This permits the conversion of land functions along with population development and activities affecting changes in land use. Pandaan is located southwest of the capital city of Pasuruan (Bangil Sub-district) and $50 \mathrm{~km}$ from the south of Surabaya. It borders by Gempol and Beji Subdistricts in the north, Rembang and Sukorejo Sub-districts in the east, Prigen and Sukorejo Sub-districts in the south, and Gempol and Prigen Sub-districts in the west. The land-use area changes in 2020 is 456.68 ha (Prayitno et al., 2020). 

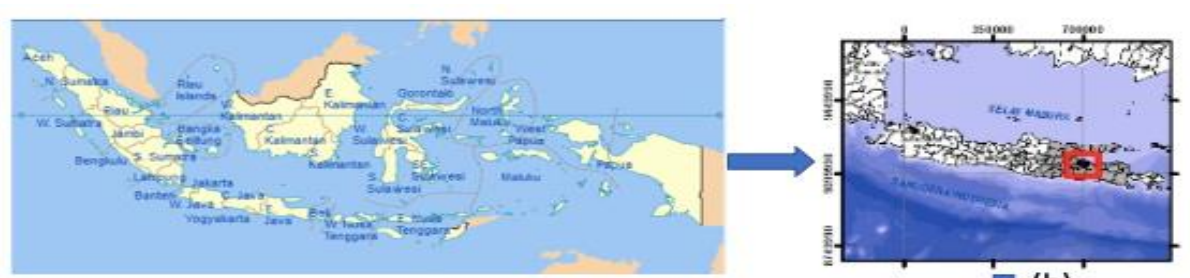

(a)
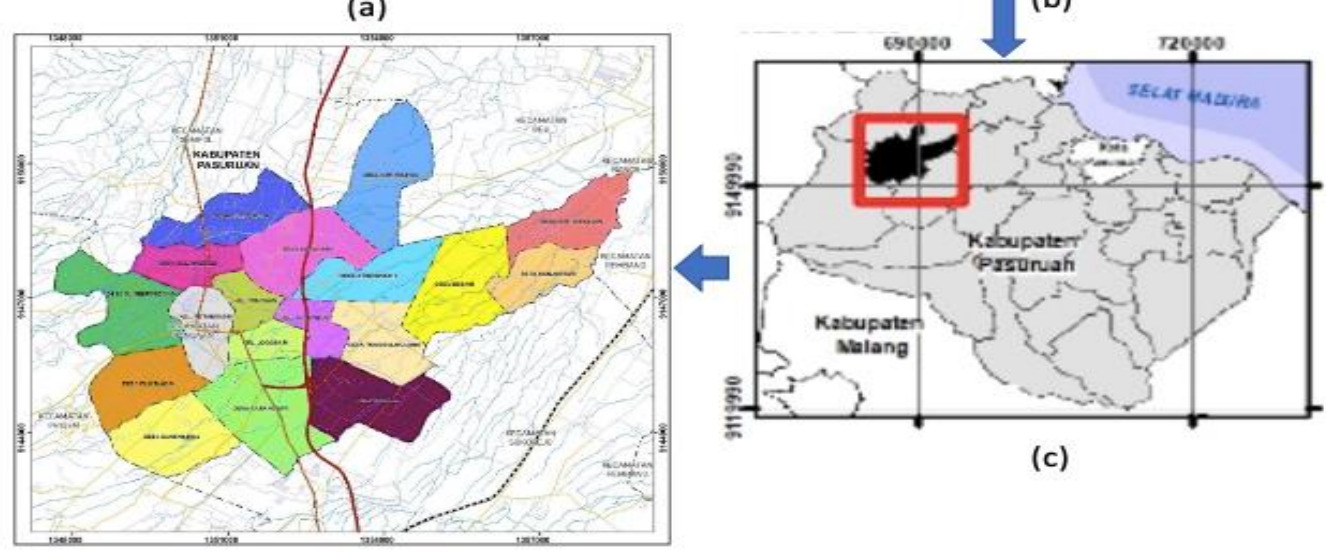

(c)

(d)

Figure 2. Administration Map of Pandaan Sub-district

(a) Indonesia, (b) East Java, (c) Pasuruan Regency, (d) Pandaan District Source: own compilation

\subsection{Place dependence of Pandaan Sub-district}

\subsubsection{Characteristics of respondents}

The characteristics of the population in each region are different. Research respondents in Pandaan Sub-district have their characteristics. A majority of them have lived in it for 38-51 years (56,2\%), with $94 \%$ stating that they were born and lived in this sub-district. Therefore, a majority of respondents were natives.

The study aimed to determine the relationship between the place dependence of the population and land-use change. It is necessary to identify the place dependence of the population in the Pandaan Subdistrict by administering questionnaires with 33 (thirty-three) questions, following 5 (five) place dependence variables as follows:

\subsubsection{Ownership of residence}

Ownership provides a sense of place (Baldwin et al., 2017). A residence is live ina place for the daily activities of the population and should suit people's needs (Rao, 2018). There are 2 types of human needs, divided into 9 (nine) specific needs (Maslow in (Hikma, 2015)). The average respondent agreed that the 9 (nine) needs had been fulfilled in current residence with an average percentage of $55.78 \%$. The majority of their needs were met in their homes. The comfort felt indicates that the population is functionally attached to Pandaan Sub-district (Graph 1). 


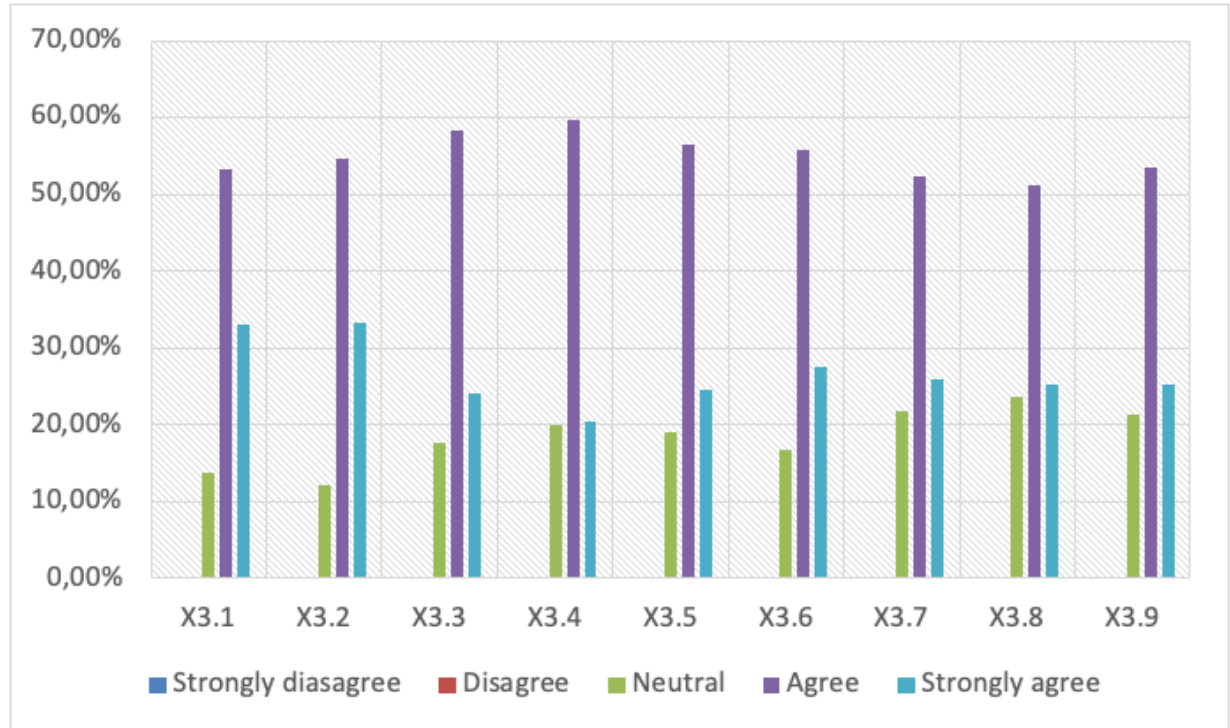

Graph 1. Respondents' answers on residential ownership

Source: own compilation

\subsubsection{Environmental quality}

An assessment of the residential environment provides critical information. A good environment for the population creates a place dependence (William \& Haryani, 2019). Respondents assessed their residential environment by looking at 6 environmental aspects (Amerigo \& Aragones, 1997). Most of the respondents agreed that environmental aspects were good, and therefore, they were comfortable and attached to Pandaan Sub-district. However, $8.2 \%$ of respondents disagreed because they felt the environment was not good due to damaged roads, substandard water discharge, congested residential environment, houses far from hospitals, and unfamiliarity with the neighbors (Graph 2).

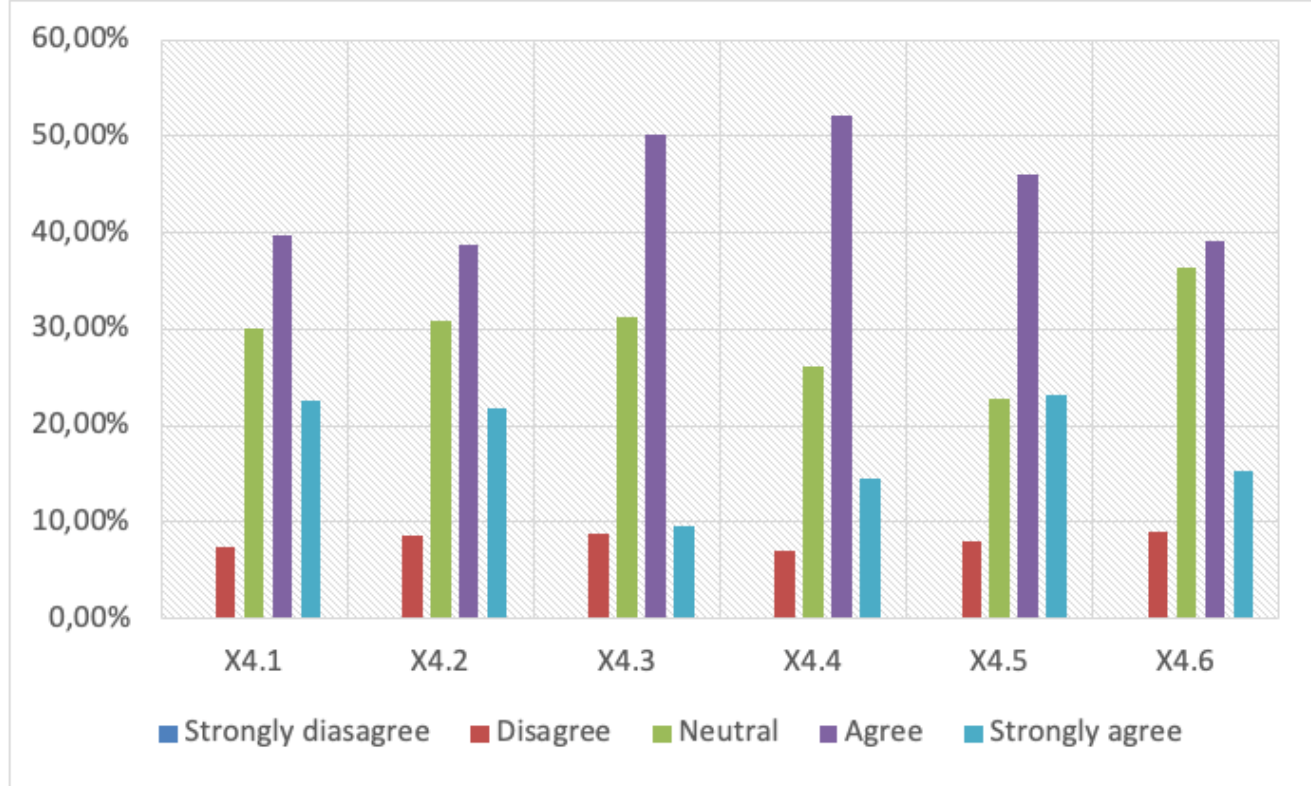

Graph 2. Respondents' answers on environmental quality

Source: own compilation 


\subsubsection{Income that fulfills the needs}

Insufficient income is a source of financial stress for the population. This is attributed to the financial inadequacy in meeting personal and family needs (So Hyun-Jo in (Sina, 2012)). To overcome this issue, it is necessary to provide adequate income for the population based on the 5 physiological needs (Maslow in Hikma, 2015). The income of the majority of respondents ranges between 1,000,000 (IDR) to 2,000,000 (IDR) per month. A total of $44 \%$ of respondents agreed that their income could fulfill their needs, and therefore, they were attached to Pandaan Sub-district (Graph 3).

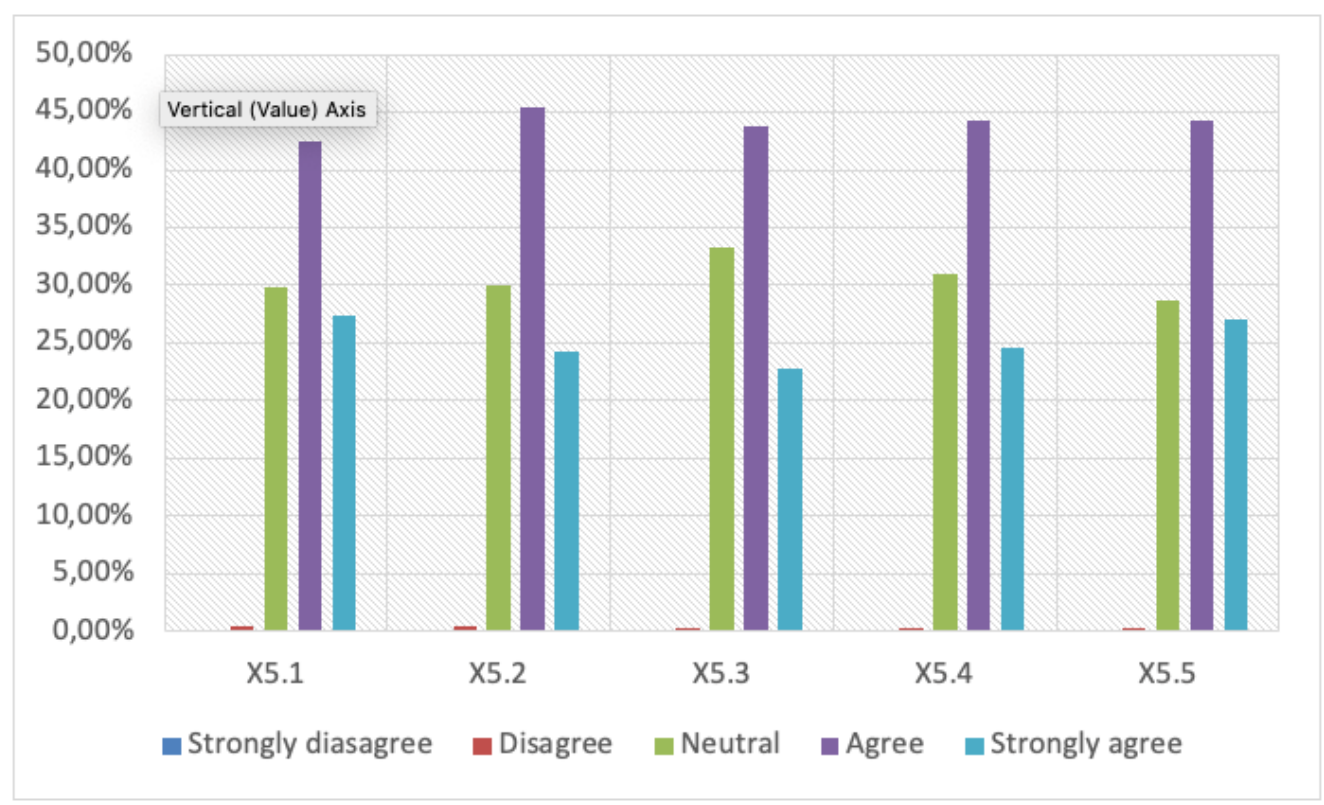

\section{Graph 3. Respondents' answers on income}

Source: own compilation

\subsubsection{Accessibility}

Accessibility is the ease of the residents' access to public facilities, nature, hobby areas, and workplaces for daily activities, facilitating the realization of the goals of the population. Residents access these places with affordable modes (Williams et al. in Haryani 2019, Trabka, 2019). Respondents use private vehicles for their activities, with $40.93 \%$ having a private transportation mode. This makes the cost of reaching a needed location affordable. For this reason, the respondents were attached to the Pandaan Sub-district (Graph 4). 


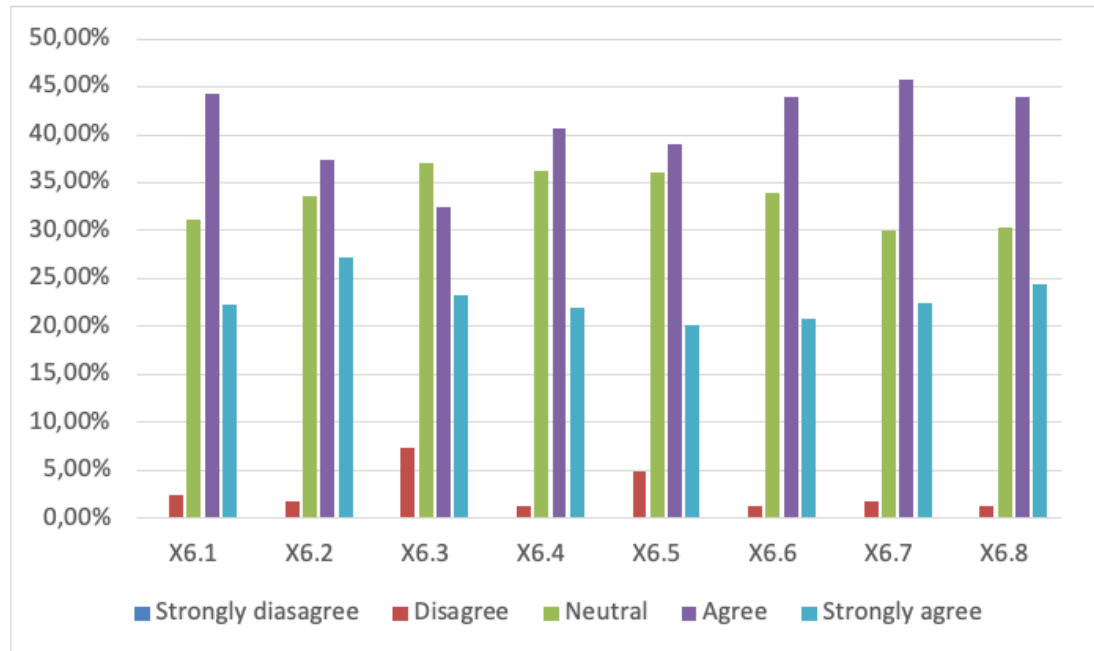

Graph 4. Respondents' answers on accessibility

Source: own compilation

\subsubsection{Career development}

Proper career development is a comfortable feeling people have while working in an area due to the availability of satisfying jobs (Trabka, 2019). A balanced workload is needed to achieve job satisfaction. The workload is the physical ability of humans to accept work. It is measured using mental, physical, and time aspects (Manuaba in (Hadidya et al., 2018)). The majority of respondents worked for 8 hours, using private vehicles to reach workplaces. They agreed to have satisfying jobs, with a sense of comfort and attachment to the Pandaan Sub-district (Graph 5).

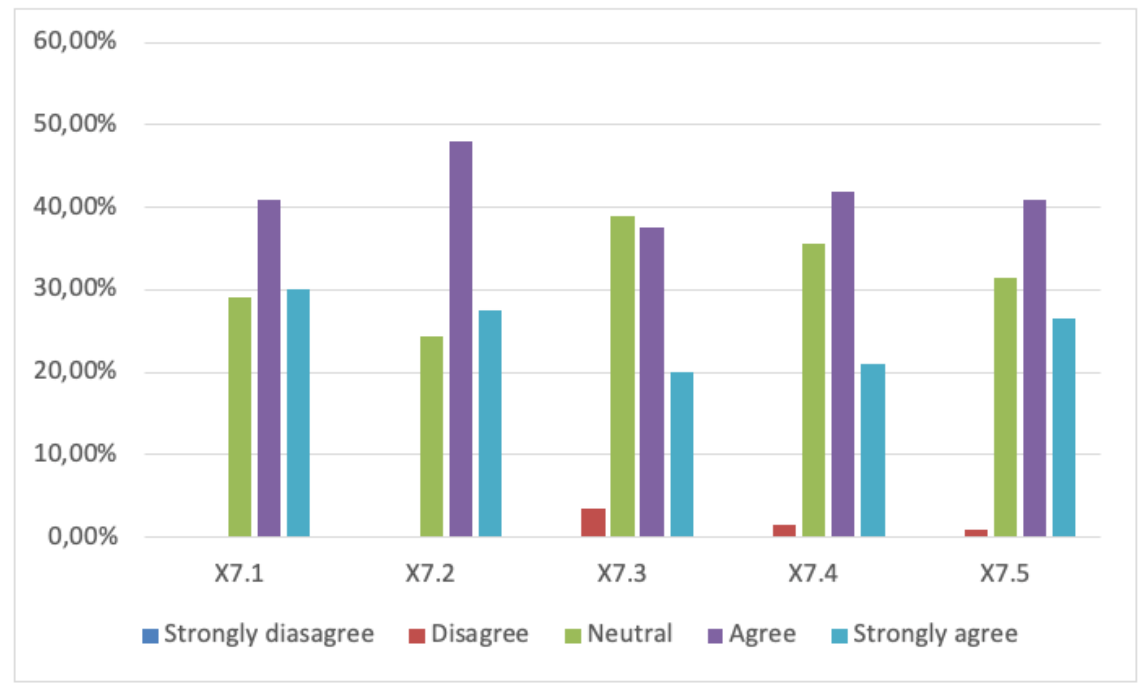

Graph 5. Respondents' answers on career development

Source: own compilation

\subsection{Attitudes and decisions of the population}

Attitudes towards land change in support for development or protection and characteristics of rural landscapes are responded to through a scale of interest (Lokocz, Ryan \& Sadler, 2011). Attitude patterns 
towards development determine the decisions of the population (Graph 6). Respondents think and respond to various development situations in Pandaan Subdistrict following their needs. Although the population wants to support development, the attitude is accompanied by land protection. A total of $69 \%$ of respondents are against changing their land use.

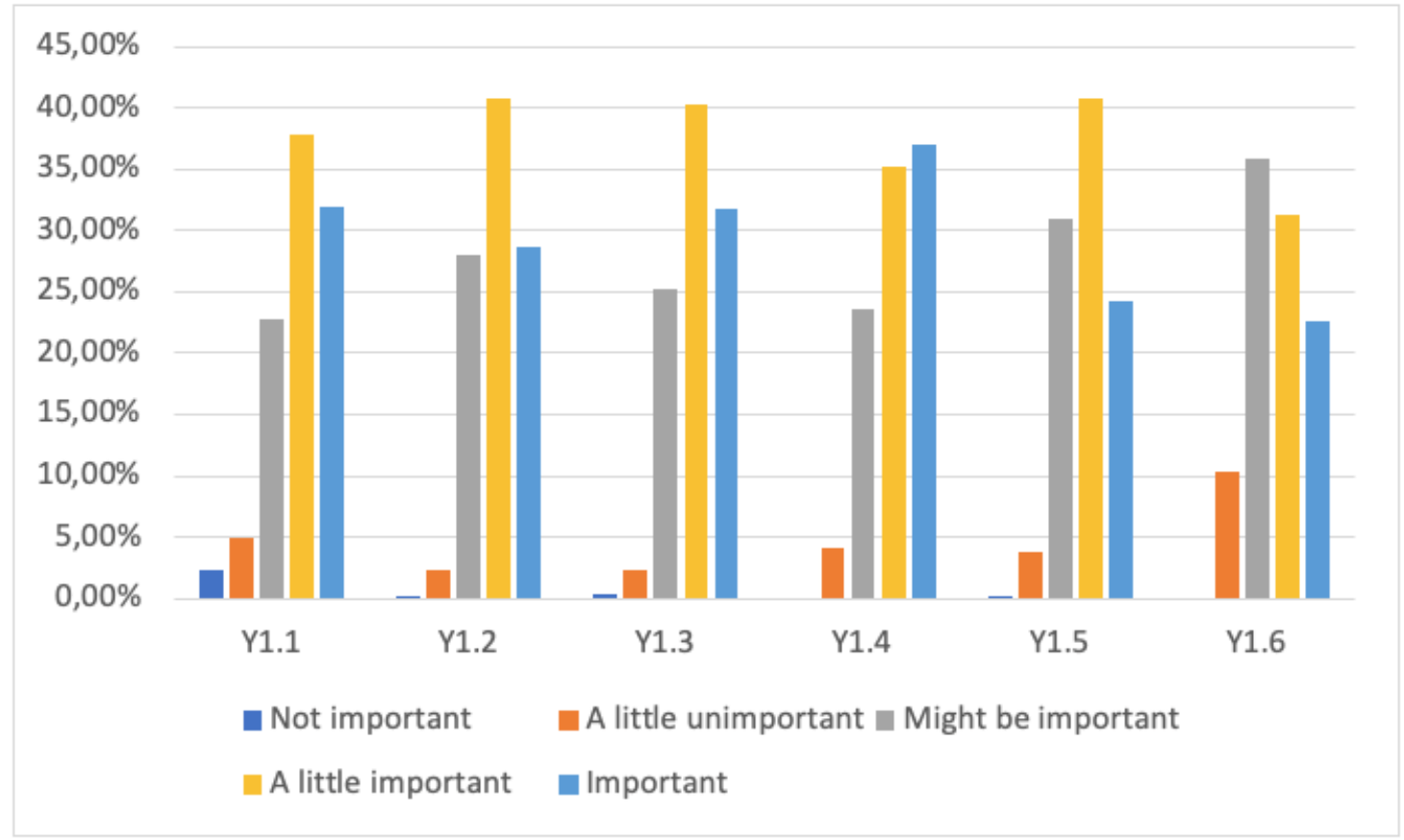

Graph 6. Respondents' answers on attitudes towards development

Source: own compilation

\subsection{Relationship of place dependence with land use change}

Land-use change from non-built to build land or vice versa is not merely a physical phenomenon of reduced land. It is a dynamic phenomenon involving human life aspects. It is closely related to changes in the economic, socio-cultural, and political orientation of the community (Winoto \& Rusmi, 2019). Conversion of land use for regional development cannot be avoided (Giuseppina, 2012). The developments occur to fulfil the increasing needs of the population. It is associated with increased demand for a better quality of life, which is the primary goal. Having a comfortable life and work is part of place dependence (Trabka, 2019). Therefore, the goals of the residents affect the conversion of land use in an area.

The respondents' characteristics revealed that land ownership, environmental quality, income, accessibility, and career development reduce the decision to change the land. According to research Trabka (2019) that states achieving the population's goals requires a good environment, sufficient income, accessible and affordable infrastructure, and a promising career. According to Baldwin et al. (2017), a sense of ownership also contributed to the population's place dependence. Trabka (2019) states that achieving the population's goals requires a good environment, sufficient income, accessible and affordable infrastructure, and a promising career. According to Baldwin et al. (2017), a sense of ownership also contributed to the population's place dependence.

The next step after knowing the characteristics of the population's and the population's views on land development and the decision to change/sell land is to determine whether there is a relationship between the two characteristics mentioned above (place dependence and land-use change). We employ partial least 
squares (PLS) analysis techniques, with the results providing an overview of the relationship between latent variables (Chin \& Newsted in (Ghozali \& Hengky, 2015).

The evaluation of the measurement model, also known as the evaluation of the outer model, is performed to determine validity and reliability. The convergent and discriminant validity of the manifest variables that form the latent variables and the composite reliability and Cronbach's alpha are evaluated (Chin in (Ghozali, 2008).

1. Examine convergent validity as the first step. Convergent validity is determined by examining the loading factor's value on each indicator's variable (manifestation variable). If an indicator has a loading factor value greater than 0.5 , it is said to be valid. A valid indicator can measure its latent variables (Sholihin \& Ratmono, 2013).

Appendix 1 contains data on the loading factors values for each indicator. The loading factors, apart from validity, have a contribution of indicators to each variable. In the residence ownership variable, indicator X3.5 has the largest contribution. This means that the house's needs are the priorities for residents and attract them to the subdistricts. The indicator X4.3 becomes the biggest contribution in the environmental quality variable, meaning that a not-dense home environment is the largest assessment of environmental comfort affecting attachment. Third, the income variable has indicator X5.3 as the biggest contribution, meaning that the need for home-based resting at no cost provides a sense of financial freedom and comfort. Indicators X6.5 and X6.6 for accessibility variables show that the Pandaan Sub-district, with an un-built land area of $70.33 \%$, provides affordable access to natural areas through private vehicles and public facilities. Lastly, career development variables have indicators X7.4 and X7.5 with the biggest contribution. In latent variables, the attitude towards development as the greatest contribution is the presumption of putting aside land for public recreation (Y1.3) with a value of 0.825 .

2. The second process involves looking at the composite reliability, average variance extracted (AVE) and Cronbach's alpha. It examines the value of composite reliability and average variance extracted (AVE). Both values have been fulfilled by all variables with AVE values above 0.5 and composite reliability above 0.7 . Therefore, this research has validity and credibility in explaining the variables used.

Table 3

Composite Reliability Values and AVE

\begin{tabular}{|l|c|c|c|}
\hline & Cronbach's Alpha & $\begin{array}{c}\text { Composite } \\
\text { Reliability }\end{array}$ & $\begin{array}{c}\text { Average Variance } \\
\text { Extracted (AVE) }\end{array}$ \\
\hline Accessibility & 0,861 & 0,891 & 0,508 \\
\hline Origin & 1,000 & 1,000 & 1,000 \\
\hline Ownership of residence & 0,878 & 0,903 & 0,509 \\
\hline Decision to Change Land & 1,000 & 1,000 & 1,000 \\
\hline Environmental quality & 0,814 & 0,866 & 0,520 \\
\hline Length of stay & 1,000 & 1,000 & 1,000 \\
\hline Career development & 0,864 & 0,902 & 0,649 \\
\hline Income that meets the needs & 0,897 & 0,924 & 0,707 \\
\hline Attitudes towards land development & 0,807 & 0,862 & 0,517 \\
\hline
\end{tabular}

Source: an analysis, 2020

Convergent validity examines the loading factor value with a minimum value of 0.5 ((Can \& Asan, 2020; Sholihin \& Ratmono, 2013). In Table 3, it is clear that all the loading factor values of each variable's indicators are above 0.5. Therefore, the indicators are consistent and appropriate for research in Pandaan Sub-district.

The following step is to perform an Inner Model Evaluation. 
The evaluation of the structural model, also known as the evaluation of the inner model, aims to predict the relationship between latent variables (Geisser in (Ghozali \& Hengky, 2015)). Place dependence, attitudes toward development, and the decision to change land use are the latent variables that will be observed in relation to the relationship. Checking the $\mathrm{R}$-square value, path coefficient, and indirect effect reveals the relationship between these latent variables.

The analysis shows that the R-square value of each endogenous latent variable in this study. According to Chin (1998), an R square value of 0.67 is considered strong, 0.33 is considered moderate, and 0.12 is considered weak. The endogenous place dependence latent variable has a value of 0.994 or 99.4 percent, indicating that the latent variable used to measure place dependence (length of stay, origin, consideration of choosing land, environmental quality, income to meet needs, accessibility, and satisfying work) is already strong. Meanwhile, the endogenous latent variables of the decision to sell land and attitudes toward land development have $\mathrm{R}$ square values of 0.37 or 37 percent and 0.123 or 12.3 percent, respectively, classified as weak, implying that a structural model does not measure other latent variables.

An examination of the relationship between place dependence of population and land-use change in the Pandaan Sub-district is shown by the path coefficient value and indirect effects (Table 4 and Table 5). The path coefficient value explains the direct relationship between variables with arrows. Path coefficients with negative values are the length of stay and income variables, suggesting that the place dependence relationship is negative. If the income owned meets the needs of the population that has long lived in the area, the place dependence tends to decrease. Origin, consideration of ownership, environmental quality, and job satisfaction positively relate to place dependence. Similarly, the place dependence, attitudes toward development, and decisions to change land have a positive relationship.

Environmental quality has a path coefficient of 0.787 and $\mathrm{p}$-values $<0,005$ (significant). This is a strong relationship since the standard deviation is above 0.1 (Table 4). This is the largest coefficient value with the greatest influence in determining the place dependence of the respondent. Therefore, to quickly increase the place attachment, the respondent's residence needs to have a good environmental quality, fulfilling all aspects such as harmonious neighbourly relationships, a safe residential environment, a not-dense residential environment, efficient residential infrastructure, and, and efficient health facilities. Reducing the housing density to lower the loading factor value should be prioritized for improvement.

Table 4

Path coefficient values

\begin{tabular}{|c|c|c|c|}
\hline Relationship between variables & p-values & Values index & $\begin{array}{l}\text { Deviation } \\
\text { standard }\end{array}$ \\
\hline Accessibility -> Place Dependence & $<0,105$ & 0,211 & 0,168 \\
\hline Origin -> Place Dependence & $<0,066$ & 0,177 & 0,118 \\
\hline Ownership of residence -> Place Dependence & $<0,291$ & 0,091 & 0,165 \\
\hline Environmental quality -> Place Dependence & $<0,001$ & 0,787 & 0,156 \\
\hline Length of stay -> Place Dependence & $<0,085$ & $-0,165$ & 0,120 \\
\hline Career development -> Place Dependence & $<0,045$ & 0,231 & 0,157 \\
\hline Income that meets the needs $->$ Place Dependence & $<0,372$ & $-0,051$ & 0,136 \\
\hline Place Dependence -> Decision to Change Land & $<0,001$ & 0,056 & 0,062 \\
\hline $\begin{array}{l}\text { Place Dependence -> Attitudes towards land } \\
\text { development }\end{array}$ & $<0,001$ & 0,350 & 0,041 \\
\hline $\begin{array}{l}\text { Attitudes towards land development }->\text { Decision to } \\
\text { Change Land }\end{array}$ & $<0,001$ & 0,166 & 0,047 \\
\hline
\end{tabular}

Source: an analysis, 2020 
The path calculation (Table 4) from place dependence (PC) to attitudes toward land development (ATLD), decision to change the land (DCL) are significant and positive ( $\mathrm{p}$-value $<0,001$ ) less than 0,05 . So are the ATDL to DCL the value of path analysis is significant $(\mathrm{p}$-value $<0,001)$ and positive $(0,166)$. This shows that the higher place dependence will increase the resident to protect their land.

The second process involves analysing the indirect relationship between variables, shown by the value of indirect effects. The results show that income that fulfils the needs and length of stay has a negative indirect relationship with the decision to change land and a direct relationship with place dependence. Therefore, if the population has income and has long lived in Pandaan Sub-district, it tends not to be attached, with a likelihood to change the land owned (Figure 3).

Other exogenous latent variables such as origin, residence ownership, environmental quality, accessibility, and satisfying job, have a positive indirect relationship. Therefore, in case the assessment of the variables is good, the population tends to be attached to its residence, with no likelihood to change the land. The biggest contribution in the indirect relationship to the latent variable "decision to change land" is environmental quality. It seemed to give a big consideration in the decision to change the land in Pandaan Sub-district.

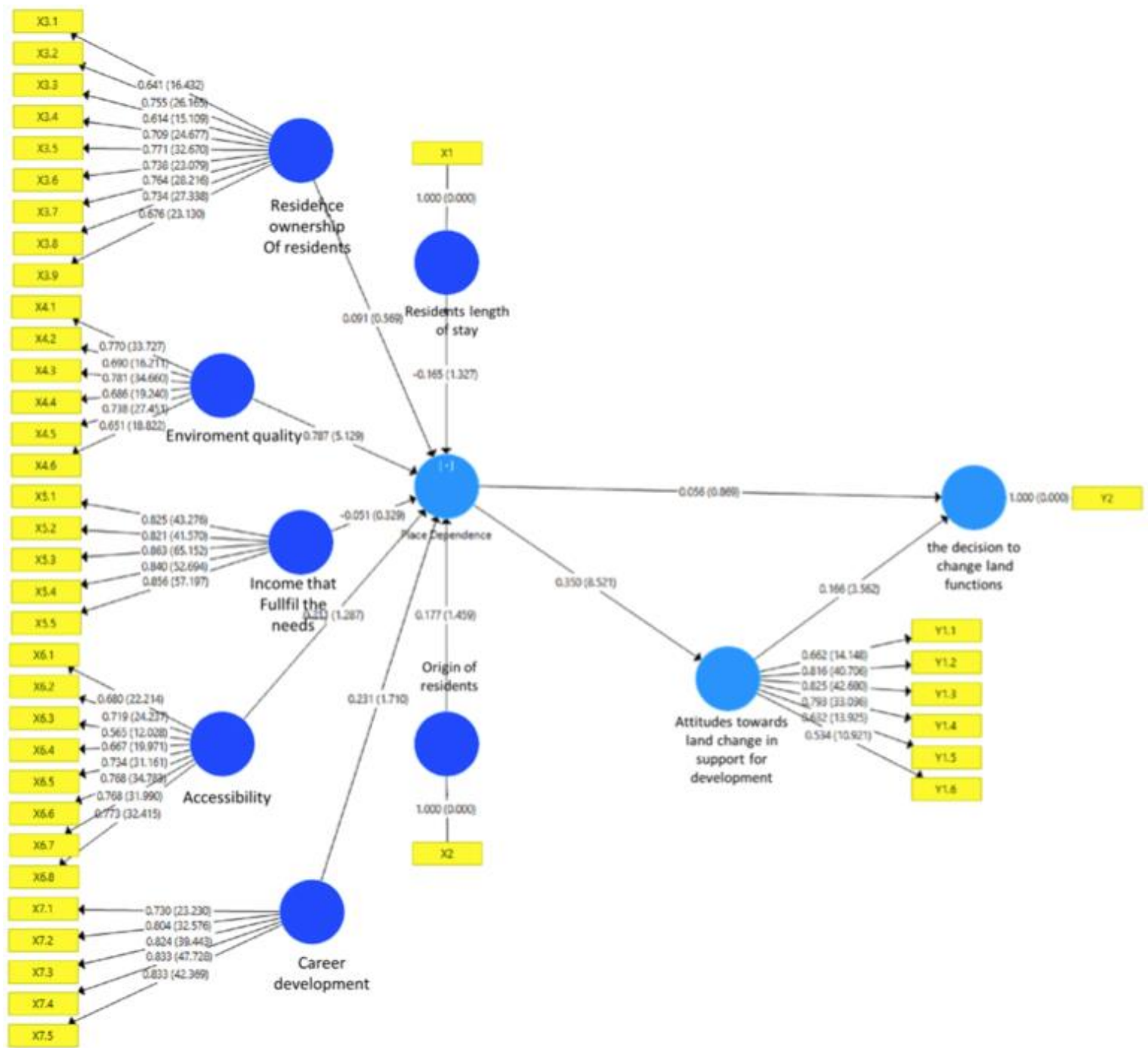

Figure 3. Structural equation model of place dependence on land used change

Source: own compilation 
Place dependence has a positive indirect and direct relationship with the decision to change the land. It is a sign of the purpose of the population to live and work comfortably, therefore, the place attachment in Pandaan Sub-district felt by residents determines the decision not to change the land owned. From the path value, place dependence toward attitude for land development has a significant effect on changing the land ( $\mathrm{p}$-value $<0,005$ ). If place dependence is higher, attitude toward development will increase and affect the decision to change the land (Table 5).

Table 5

Indirect effect value

\begin{tabular}{|c|c|c|}
\hline Relationship between variables & p-values & $\begin{array}{l}\text { Values } \\
\text { index }\end{array}$ \\
\hline \multicolumn{3}{|l|}{ Indirect relationship with one mediation } \\
\hline Accessibility -> Place Dependence -> Decision to Change Land & $<0,281$ & 0,012 \\
\hline Origin -> Place Dependence $->$ Decision to Change Land & $<0,247$ & 0,010 \\
\hline Ownership of residence -> Place Dependence -> Decision to Change Land & $<0,376$ & 0,005 \\
\hline Environmental quality -> Place Dependence -> Decision to Change Land & $<0,018$ & 0,044 \\
\hline Length of stay $->$ Place Dependence $->$ Decision to Change Land & $<0,261$ & $-0,009$ \\
\hline Career development -> Place Dependence -> Decision to Change Land & $<0,421$ & 0,013 \\
\hline Income that meets the needs $->$ Place Dependence $->$ Decision to Change Land & $<0,251$ & $-0,003$ \\
\hline \multicolumn{3}{|l|}{ Indirect relationship with two mediations } \\
\hline $\begin{array}{l}\text { Accessibility }->\text { Place Dependence }->\text { Attitudes towards land development -> } \\
\text { Decision to Change Land }\end{array}$ & $<0,001$ & 0,012 \\
\hline $\begin{array}{l}\text { Origin -> Place Dependence -> Attitudes towards land development -> Decision } \\
\text { to Change Land }\end{array}$ & $<0,084$ & 0,010 \\
\hline $\begin{array}{l}\text { Ownership of residence }->\text { Place Dependence }->\text { Attitudes towards land } \\
\text { development }->\text { Decision to Change Land }\end{array}$ & $<0,001$ & 0,005 \\
\hline $\begin{array}{l}\text { Environmental quality }->\text { Place Dependence }->\text { Attitudes towards land } \\
\text { development }->\text { Decision to Change Land }\end{array}$ & $<0,005$ & 0,046 \\
\hline $\begin{array}{l}\text { Length of stay }->\text { Place Dependence }->\text { Attitudes towards land development -> } \\
\text { Decision to Change Land }\end{array}$ & $<0,104$ & $-0,010$ \\
\hline $\begin{array}{l}\text { Career development -> Place Dependence -> Attitudes towards land development } \\
\text {-> Decision to Change Land }\end{array}$ & $<0,061$ & 0,013 \\
\hline $\begin{array}{l}\text { Place Dependence -> Attitudes towards land development -> Decision to Change } \\
\text { Land }\end{array}$ & $<0,001$ & 0,058 \\
\hline $\begin{array}{l}\text { Income that meets the needs -> Place Dependence }->\text { Attitudes towards land } \\
\text { development } \\
\text {-> Decision to Change Land }\end{array}$ & $<0,381$ & $-0,003$ \\
\hline
\end{tabular}

Source: an analysis, 2020

The relationship between place dependence and land use change in the Pandaan sub-district has two relationships. The relationship is a direct and indirect relationship (Table 6). On the basis of the T-test of the accepted hypothesis, there is an indirect relationship between the dependence of the population on the place and people's decision to change land. This relationship occurred or has mediating variables, namely; the attitude toward land change in support development. Mediating variables are variables that influence the value of endogenous variables and exogenous variables that are interdependent (Hair et al, 2017). The results of the analysis show that the higher the place dependence of the population in Pandaan sub-district, the population will tend to withstand physical changes in their environment so that the population will not change the land. 
Coefficient of relationship with "Decision to Change Land"

\begin{tabular}{|c|c|c|c|}
\hline \multirow{2}{*}{ Variable } & \multirow{2}{*}{ Effect size } & Direct Relation & Indirect Relation \\
\cline { 3 - 4 } & & P-value & P-value \\
\hline Place dependence & 0,10 & 0,185 & 0,002 \\
\hline
\end{tabular}

Source: an analysis, 2020

Furthermore, based on the $\mathrm{T}$ test the indirect relationship of the place dependence of the population and land use change is significantly influenced by environmental quality ( $p$ value: 0,002 ) less than 0,05 . This shows how important it is to protect the environment where people live. Environmental aspects to maintain its quality are to maintain harmonious relations between neighbours, have a safe environment, maintain the density of houses in the environment, and maintain the condition of infrastructure, conditions of residential facilities and health facilities. This is important because it will reduce the population's decision to change the land owned while reducing the intensity of the phenomenon of land use change in Pandaan sub-district.

\section{CONCLUSION}

Conversion of land functions occurs in Pandaan Sub-district, as evidenced by changes in land use. The land-use area has changed, with the largest changes occurring in the use of wet agricultural land or rice fields. An extensive change that occurred is 456.68 ha. Furthermore, $69 \%$ of respondents want to protect the land owned because it has supported community activities. The main activity of the population is agriculture, and therefore, there is no need to change the land owned.

The residents feel attached to the area they live in. The respondents felt their goal of living and working comfortably was met. The most important factor influencing the place dependence of the population is environmental quality. Environmental conditions in Pandaan Sub-district are generally good, providing a sense of comfort to the population.

Place dependence and land-use change in Pandaan Sub-district have a positive indirect relationship. The residents maintain the current landscape conditions in case they are increasingly attached to their residence. Furthermore, the relationship between place dependence and land-use conversion decisions occurs because of environmental quality. Good environmental conditions offer a sense of comfort to the population, causing an attachment. This affects the population's decision to change the land (not to change the land).

The relationship is a direct and indirect relationship. There is an indirect relationship between the dependence of the population on the place and people's decision to change land. This relationship occurred or has mediating variables, namely; the attitude towards land development. The results of the analysis show that the higher the place dependence of the population in Pandaan sub-district, the population will tend to withstand physical changes in their environment so that the population will not change the land. As a result, the higher place dependence in the Pandaan sub-district will tend to keep the land, allowing sustainable agriculture.

\section{ACKNOWLEDGEMENT}

This research was supported by the project, which has received funding from the Brawijaya University research program for Assistant Professor Research Grant, Grant Agreement Number 41/UN10.FO7/PN/2020 


\section{REFERENCES}

Amerigo, M., \& Aragones, J. I. (1997). A theoretical and methodological approach to the study of residential satisfaction. Journal of Environmental Psychology, 17(1), 47-57. https://doi.org/10.1006/jevp.1996.0038

Anton, C. E., \& Lawrence, C. (2016). The relationship between place attachment, the theory of planned behaviour and residents' response to place change. Journal of Environmental Psychology, 47, $145-154$. https://doi.org/10.1016/j.jenvp.2016.05.010

Aulia Rusmi, S. (2019). Keterkaitan Place Attachment terhadap Keputusan Mengubah Laban di Kecamatan Pandaan. Skripsi: Universitas Brawijaya.

Baldwin, C., Smith, T., \& Jacobson, C. (2017). Love of the land: Social-ecological connectivity of rural landholders. Journal of Rural Studies, 51, 37-52. https://doi.org/10.1016/j.jrurstud.2017.01.012

Burley, D. M. (2010). Losing Ground: identity and land loss in coastal Louisiana. The University Press of Mississippi is a member of the Association of American University Presses.

Butu, H. M., Hashim, A. H. Bin, \& Ahmad, N. (2018). Influence of place identity and place dependence on resilience towards Boko Haram Insurgency among Maiduguri Residents in Borno State, Nigeria. Journal of Environmental Science, Toxicology and Food Technology. https://doi.org/10.9790/2402-1207011220

Can, A., \& Asan, U. (2020). A study on the adoption of smart home devices: PLS structural equation modeling. In Industrial Engineering in the Digital Disruption Era. https:/ / doi.org/10.1007/978-3-030-42416-9_21

Christy, \& Sahrani, R. (2016). Hubungan Place Attachment dengan Perilaku Prososial Relawan Sosial. Provitae Jurnal Psikologi Pendidikan, 8(2), 68-87.

Clarke, D., Murphy, C., \& Lorenzoni, I. (2018). Place attachment, disruption and transformative adaptation. Journal of Environmental Psychology. https://doi.org/10.1016/j.jenvp.2017.12.006

Ernawati, J. (2014). Hubungan Aspek Residensial dengan Place Identity dalam Skala Urban. Journal of Environmental Engineering \& Sustainable Technology, 1(1), 21-32. https://doi.org/10.21776/ub.jeest.2014.001.01.4

Ganji, S. F. G., Johnson, L. W., \& Sadeghian, S. (2020). The effect of place image and place attachment on residents' perceived value and support for tourism development. Current Issues in Tourism, 1-15. https://doi.org/10.1080/13683500.2020.1784106

Ghozali, I. (2008). Structural equation modeling, metode alternatif dengan partial least square. Badan Penerbit Universitas Diponegoro, Semarang.

Ghozali, I., \& Hengky, L. (2015). Konsep, teknik dan aplikasi menggunakan program smart PLS 3.0. In Universitas Diponegoro. Semarang. https://openlibrary.telkomuniversity.ac.id/pustaka/117046/partial-least-squares-konsepteknik-dan-aplikasi-menggunakan-program-smartpls-3-0-2-e-.html

Hadidya, S., Rahmawan, \& Susatyo, Y. S. (2018). Hubungan antara Persepsi Beban Kerja dengan Kepuasan Kerja Karyawan [Universitas Muhammadiyah Surakarta]. http://eprints.ums.ac.id/64405/

Haryani, E., Rukmi, W. I., \& Setyono, D. A. (2019). Hubungan Place Attachment dengan Partisipasi Masyarakat dalam Program PLPBK di RW 04 Kelurahan Polehan. Jurnal Tata Kota Dan Daerah, 11(1), 1-10. https://doi.org/http://dx.doi.org/10.21776/ub.takoda.2019.011.01.1

Hasyim, A. W. (2020). Determination of land cover as landslide factor based on multitemporal raster data in Malang Regency. International Journal of GEOMATE, 18(69), 254-261. https://doi.org/10.21660/2020.69.71522

Hikma, N. (2015). ASPEK PSIKOLOGIS TOKOH UTAMA DALAM NOVEL SEPATU DAHLAN KARYA KHRISNA PABICHARA (Kajian Psikologi Humanistik Abraham Maslow). Jurnal Humanika, 15(3).

Jatmiko, A. (2016). Sense of place dan social anxiety bagi Mahasiswa Baru Pendatang. KONSELI: Jurnal Bimbingan Dan Konseling (E-Journal), 3(2), 155-160.

Kock, N. (2015). One-tailed or two-tailed P values in PLS-SEM? International Journal of E-Collaboration, 11(2), 1-7. https://doi.org/10.4018/ijec.2015040101

Lai, P. H., \& Kreuter, U. P. (2012). Examining the direct and indirect effects of environmental change and place attachment on land management decisions in the Hill Country of Texas, USA. Landscape and Urban Planning, 104(3-4), 320-328. https://doi.org/doi.org/10.1016/j.landurbplan.2011.11.007

Lin, C. C., \& Lockwood, M. (2014). Forms and sources of place attachment: Evidence from two protected areas. Geoforum, 53, 74-81. https://doi.org/10.1016/j.geoforum.2014.02.008 
Lokocz, E., Ryan, R. L., \& Sadler, A. J. (2011). Motivations for land protection and stewardship: Exploring place attachment and rural landscape character in Massachusetts. Landscape and Urban Planning, 99(2), 65-76. https://doi.org/10.1016/j.landurbplan.2010.08.015

Malingreau, J. P. (1977). Apropose Land Cover/ Land use Classification and its use with remote Sensing Data In Indonesia. Yogyakarta: Fakultas Geografi. The Indonesian Journal of Geography, 33(7).

Prayitno, G., Dinanti, D., Rusmi, S. A., Surjono, \& Dwi Maulidatuz, Z. (2019). Place Attachment Index of Landowners in Pandaan Sub-District, Pasuruan Regency, Indonesia. IOP Conference Series: Earth and Environmental Science. https://doi.org/10.1088/1755-1315/239/1/012045

Prayitno, G., Sari, N., Hasyim, A. W., \& Nyoman, S. W. (2020). Land-use prediction in Pandaan District pasuruan regency. International Journal of GEOMATE, 18(65), 64-71.

Prayitno, G., Sari, N., Hidayat, A. R. T., Nyoman Widhi, S. W., \& Dwi Maulidatuz, Z. (2019). Soil/land use changes and urban sprawl identification in Pandaan District, Indonesia. International Journal of GEOMATE. https://doi.org/10.21660/2019.53.18243

Prayitno, G., Surjono, Hidayat, A. R. T., Subagiyo, A., \& Paramasasi, N. K. (2018). Factors that effect to land use change in Pandaan District. IOP Conference Series: Earth and Environmental Science. https://doi.org/10.1088/1755$1315 / 202 / 1 / 012006$

Rao, J. (2018). Fundamental Functionings of Landowners: Understanding the relationship between land ownership and wellbeing through the lens of 'capability.' Land Use Policy, 72(December 2017), 74-84. https://doi.org/10.1016/j.landusepol.2017.12.033

Raymond, C. M., Brown, G., \& Weber, D. (2010). The measurement of place attachment: Personal, community, and environmental connections. Journal of Environmental Psychology, 30(4), $422-434$. https://doi.org/10.1016/j.jenvp.2010.08.002

Raymond, C. M., Kyttä, M., \& Stedman, R. (2017). Sense of place, fast and slow: the potential contributions of affordance theory to sense of place. In Frontiers in Psychology (Vol. 8, p. 1674). https://www.frontiersin.org/article/10.3389/fpsyg.2017.01674

Rusmi, S. A. (2019). Keterkaitan Place Attachment terbadap Keputusan Mengubah Lahan di Kecamatan Pandaan. Universitas Brawijaya.

Sholihin, M., \& Ratmono. (2013). Analisis SEM-PLS dengan Wrap PLS 3.0 untuk Hubungan Nonlinier dalam Penelitian Sosial dan Bisnis. Penerbit Andi Offset.

Siciliano, G. (2012). Urbanization strategies, rural development and land use changes in China: A multiple-level integrated assessment. Land Use Policy, 29(1), 165-178. https://doi.org/10.1016/j.landusepol.2011.06.003

Sina, P. G. (2012). analisis stres finansial pada gender. Jurnal Ekonomi \& Pendidikan, 9(1), $102-112$. https://journal.uny.ac.id/index.php/jep/article/view/4157/3600

Sina, P. G., \& Raturomon, L. T. (2015). Analisis stres finansial pada gender. Jurnal Ekonomi Dan Pendidikan. https://doi.org/10.21831/jep.v9i1.4157

Smith, K. M. (2011). The Relationship between Residential Satisfaction, Sense of Community, Sense of Belonging and Sense of Place in a Western Australian Urban Planned Community. Edith Cowan University.

Suntikul, W., \& Jachna, T. (2016). The co-creation/place attachment nexus. Tourism Management. https://doi.org/10.1016/j.tourman.2015.06.026

Trąbka, A. (2019). From functional bonds to place identity: Place attachment of Polish migrants living in London and Oslo. Journal of Environmental Psychology, 62, 67-73. https://doi.org/10.1016/j.jenvp.2019.02.010

Udah, H. (2019). Searching for a Place to Belong in a Time of Othering. Social Sciences, 8(11). https://doi.org/10.3390/socsci8110297

Verburg, P. H., Crossman, N., Ellis, E. C., Heinimann, A., Hostert, P., ... \& Zhen, L. (2015). Land system science and sustainable development of the earth system: A global land project perspective. Anthropocene, 12, $29-41$. https://doi.org/10.1016/j.ancene.2015.09.004 